\title{
Nutritive value of diets containing inactive dry yeast for lactating Saanen goats
}

\author{
Ludmila Couto Gomes ${ }^{1}$, Claudete Regina Alcalde ${ }^{1}$, Larissa Ribas de Lima1, Luciano Soares de \\ Lima ${ }^{1}$, Rodrigo de Souza ${ }^{1}$, Ana Paula Silva Possamai ${ }^{1}$
}

${ }^{1}$ Universidade Estadual de Maringá, Maringá, PR, Brasil.

\begin{abstract}
Twenty-four Saanen goats, 15 multiparous and nine primiparous, were distributed in a completely randomised design in a factorial arrangement ( 3 diets $\times 2$ parities). The treatments were soybean meal (SB), soybean + dry yeast (SBDY), or dry yeast (DY) as a protein source in the diet, and ground corn, mineral supplement, and corn silage (400 g/kg). The study was conducted to evaluate the nutritive value of diets containing inactive dry yeast as a protein source postpartum, postpeak, and during late lactation in dairy goats. To estimate the faecal excretion of indigestible material, neutral detergent fibre was used as an internal marker. The diets did not affect dry matter intake (DMI). However, DMI and nutrient intake were higher for multiparous goats compared with primiparous goats. The digestibility of dry matter and total digestible nutrients (TDN) were higher for primiparous goats in the postpartum period. In the postpeak and late lactation periods, there were no differences in digestibility of DM and nutrient between parities. The TDN was similar in the diets in the postpeak period and at lactation end. The goats fed the DY diet had lower urea nitrogen in blood. The use of inactive dry yeast to substitute soybean meal in diets for primiparous and multiparous lactating Saanen goats is a good alternative for maintaining the nutritional value of diets.
\end{abstract}

Key Words: digestibility, intake, parturition order, Saccharomyces cerevisiae, urea nitrogen

\section{Introduction}

The production and exploitation of high geneticpotential dairy goats, like Saanen, demands specific feeding, since these animals have greater requirements to support productivity (Rodrigues et al., 2007). The nutritional value of the feed must be considered during diet formulation; thus, an evaluation of its chemical composition as well as intake and digestibility is necessary, because these are the main factors that influence performance and reproductive efficiency (Pina et al., 2006).

Blood urea determination is also important in the evaluation of foods containing protein. Blood urea, which originates from the ammonia metabolism in the rumen and from the circulating amino acids, depends on the rumendegradable and undegradable protein content of the diet (Peixoto and Osório, 2007).

The commercialisation of by-products is a profitable way to minimise the environmental impact of the sugar and alcohol industries. Dry yeast, which is composed of inactive cells of Saccharomyces cerevisiae, is one of these byproducts. For animal feeding, this is a good source of nutrients such as protein, vitamins (B vitamins, especially), minerals (iron, zinc, and selenium), carbohydrates that make up the cell wall (200 to $400 \mathrm{~g} / \mathrm{kg}$ ), and a significant amount of nucleotides (Araújo and Silva, 2009). Depending on the $S$. cerevisiae strain and extraction process applied, inactive dry yeast can have from $400 \mathrm{~g} / \mathrm{kg}$ to $550 \mathrm{~g} / \mathrm{kg}$ of crude protein, on a dry matter (DM) basis (EURASYP, 2006). Thus, this product may be a good source of protein to replace traditional protein sources (e.g., soybean meal).

Inactive dry yeast is normally characterised by its very fine texture and specific smell (Amorim and Lopes, 2009), which may interfere with parameters such as dry matter intake (DMI). However, the available information on the use of inactive dry yeast in diets for Saanen dairy goats throughout lactation is scarce. In this study, it was hypothesised that inactive dry yeast could partially or totally replace soybean meal in corn silage-based diets for primiparous or multiparous dairy goats without detrimental effects on the nutritive value in the different phases of lactation.

Thus, this study was conducted to evaluate the nutritive value of diets containing inactive dry yeast as a protein source postpartum, postpeak, and during late lactation of dairy goats.

\section{Material and Methods}

The experiment was conducted at Fazenda Experimental de Iguatemi of Universidade Estadual de Maringá, southern 
Brazil. Twenty-four Saanen goats (15 multiparous and nine primiparous) were used from early lactation to the 200th day postpartum. They were distributed in a completely randomised design with a $3 \times 2$ (diets $\times$ parities) factorial arrangement of treatments. Goats were housed in single pens, fed individually for ad libitum intake $(100 \mathrm{~g} / \mathrm{kg}$ in orts) twice a day (at 9.00 hours and 16.00 hours), and milked twice daily, at 7.30 hours and 15.00 hours The milk yield was recorded at each milking.

The diets were composed of soybean meal only (SB), soybean meal + inactive dry yeast (SBDY), or inactive dry yeast only (DY), as the protein source. The other ingredients were ground corn, mineral supplement, and corn silage with a forage-to-concentrate ratio of 40:60 (Tables 1 and 2).

Inactive dry yeast is a commercially available product composed of inactive cells of $S$. cerevisiae containing about $949.9 \mathrm{~g} / \mathrm{kg}$ of DM and $401.1 \mathrm{~g} / \mathrm{kg}$ of crude protein (CP), based on DM, and was obtained by drying (using a spray drier) the biomass generated in sugar cane alcoholic fermentation. The diets were formulated with a similar

Table 1 - Chemical composition of feeds (g/kg DM)

\begin{tabular}{|c|c|c|c|c|}
\hline \multirow[b]{2}{*}{ Nutrient } & \multicolumn{4}{|c|}{ Feed } \\
\hline & $\begin{array}{l}\text { Corn } \\
\text { silage }\end{array}$ & $\begin{array}{l}\text { Ground } \\
\text { corn }\end{array}$ & $\begin{array}{c}\text { Soybean } \\
\text { meal }\end{array}$ & $\begin{array}{c}\text { Dry } \\
\text { yeast }\end{array}$ \\
\hline \multicolumn{5}{|l|}{ Postpartum } \\
\hline Dry matter $(\mathrm{g} / \mathrm{kg})$ & 313.2 & 880.5 & 877.4 & 951.6 \\
\hline Organic matter & 958.4 & 988.4 & 930.8 & 962.4 \\
\hline Ash & 41.6 & 11.6 & 69.2 & 37.6 \\
\hline Crude protein & 75.8 & 104.4 & 532.0 & 410.3 \\
\hline Rumen degradable protein $(\mathrm{g} / \mathrm{kg} \mathrm{CP})^{1}$ & 55.0 & 44.1 & 342.6 & 328.2 \\
\hline Ether extract & 25.3 & 36.9 & 29.0 & 1.8 \\
\hline Neutral detergent fibre ${ }^{2}$ & 509.9 & 130.7 & 143.4 & \\
\hline Acid detergent fibre & 302.5 & 38.0 & 77.8 & \\
\hline Total carbohydrates ${ }^{3}$ & 857.2 & 847.1 & 369.8 & 550.3 \\
\hline \multicolumn{5}{|l|}{ Postpeak } \\
\hline Dry matter $(\mathrm{g} / \mathrm{kg})$ & 270.4 & 888.4 & 891.1 & 940.0 \\
\hline Organic matter & 966.6 & 988.4 & 933.7 & 964.5 \\
\hline Ash & 33.4 & 11.6 & 66.3 & 35.5 \\
\hline Crude protein & 78.1 & 87.1 & 537.0 & 416.2 \\
\hline Rumen degradable protein $(\mathrm{g} / \mathrm{kg} \mathrm{CP})^{1}$ & 56.6 & 36.8 & 345.8 & 333.0 \\
\hline Ether extract & 33.9 & 34.5 & 14.0 & 2.6 \\
\hline Neutral detergent fibre ${ }^{2}$ & 642.6 & 150.6 & 148.9 & \\
\hline Acid detergent fibre & 365.6 & 31.5 & 82.1 & \\
\hline Total carbohydrates ${ }^{3}$ & 854.5 & 866.8 & 382.7 & 545.7 \\
\hline \multicolumn{5}{|l|}{ Late lactation } \\
\hline Dry matter $(\mathrm{g} / \mathrm{kg})$ & 245.5 & 887.2 & 888.6 & 958.3 \\
\hline Organic matter & 965.4 & 986.9 & 936.2 & 968.8 \\
\hline Ash & 34.6 & 13.1 & 63.8 & 31.2 \\
\hline Crude protein & 67.3 & 92.2 & 543.3 & 378.6 \\
\hline Rumen degradable protein $(\mathrm{g} / \mathrm{kg} \mathrm{CP})^{1}$ & 48.8 & 38.9 & 349.9 & 302.9 \\
\hline Ether extract & 31.4 & 39.4 & 17.3 & 1.4 \\
\hline Neutral detergent fibre ${ }^{2}$ & 553.4 & 134.9 & 151.9 & \\
\hline Acid detergent fibre & 272.5 & 28.4 & 72.7 & \\
\hline Total carbohydrates ${ }^{3}$ & 866.7 & 855.4 & 375.7 & 588.8 \\
\hline
\end{tabular}

chemical composition to meet the nutrient requirements of a $60 \mathrm{~kg}$ goat producing $3.0 \mathrm{~kg} / \mathrm{d}$ of milk (NRC, 2007).

The intake and apparent digestibility of DM and nutrients were evaluated during three periods: postpartum (until the 60th lactation day), postpeak (61th to 130th day), and late lactation (131th to 200th day). Samples of faeces $(30 \mathrm{~g})$ were collected for 6 consecutive days at intervals of 26 hours ( 8.00 hours, 10.00 hours, 12.00 hours, 14.00 hours, 16.00 hours, and 18.00 hours) at the beginning of each of the three periods. Samples of total mixed ration

Table 2 - Ingredients and chemical composition (g/kg DM) of diets

\begin{tabular}{|c|c|c|c|}
\hline & \multicolumn{3}{|c|}{ Diet } \\
\hline & SB & SBDY & DY \\
\hline \multicolumn{4}{|l|}{ Ingredients composition (DM basis) } \\
\hline Corn silage & 400.0 & 400.0 & 400.0 \\
\hline Ground corn & 425.3 & 397.3 & 357.9 \\
\hline Soybean meal & 166.0 & 97.2 & \\
\hline Dry yeast & & 97.2 & 234.1 \\
\hline Limestone & 3.7 & 3.4 & 3.0 \\
\hline Mineral-vitamin supplement ${ }^{1}$ & 5.0 & 5.0 & 5.0 \\
\hline \multicolumn{4}{|l|}{ Postpartum $(\mathrm{DM}$ basis; $\mathrm{n}=3)$} \\
\hline Dry matter $(\mathrm{g} / \mathrm{kg})$ & 675.0 & 679.3 & 672.3 \\
\hline Organic matter & 956.1 & 958.3 & 966.3 \\
\hline Ash & 33.9 & 32.7 & 33.7 \\
\hline Crude protein & 156.3 & 151.8 & 156.0 \\
\hline Rumen degradable protein $(\mathrm{g} / \mathrm{kg} \mathrm{CP})^{2}$ & 576.5 & 689.7 & 734.6 \\
\hline Ether extract & 31.1 & 22.6 & 20.4 \\
\hline Neutral detergent fibre ${ }^{3}$ & 290.4 & 277.3 & 255.7 \\
\hline Acid detergent fibre & 150.4 & 143.6 & 135.3 \\
\hline Indigestible neutral detergent fibre & 80.1 & 77.4 & 77.8 \\
\hline Total carbohydrates ${ }^{4}$ & 778.7 & 793.9 & 789.9 \\
\hline \multicolumn{4}{|l|}{ Postpeak (DM basis; $\mathrm{n}=3$ ) } \\
\hline Dry matter $(\mathrm{g} / \mathrm{kg})$ & 647.6 & 646.8 & 639.4 \\
\hline Organic matter & 960.2 & 965.6 & 967.0 \\
\hline Ash & 34.8 & 34.4 & 33.0 \\
\hline Crude protein & 157.0 & 161.4 & 159.4 \\
\hline Rumen degradable protein $(\mathrm{g} / \mathrm{kg} \mathrm{CP})^{2}$ & 609.5 & 639.6 & 713.7 \\
\hline Ether extract & 41.0 & 30.7 & 27.6 \\
\hline Neutral detergent fibre ${ }^{3}$ & 338.1 & 330.5 & 306.5 \\
\hline Acid detergent fibre & 174.3 & 166.2 & 157.4 \\
\hline Indigestible neutral detergent fibre & 75.9 & 73.6 & 71.1 \\
\hline Total carbohydrates ${ }^{4}$ & 767.2 & 773.5 & 780.8 \\
\hline \multicolumn{4}{|l|}{ Late lactation (DM basis; $\mathrm{n}=3$ ) } \\
\hline Dry matter $(\mathrm{g} / \mathrm{kg})$ & 639.2 & 638.8 & 641.0 \\
\hline Organic matter & 966.9 & 967.7 & 968.4 \\
\hline Ash & 33.1 & 32.3 & 31.6 \\
\hline Crude protein & 154.0 & 153.6 & 154.3 \\
\hline Rumen degradable protein $(\mathrm{g} / \mathrm{kg} \mathrm{CP})^{2}$ & 611.4 & 640.8 & 676.3 \\
\hline Ether extract & 29.7 & 30.3 & 25.7 \\
\hline Neutral detergent fibre ${ }^{3}$ & 304.5 & 287.5 & 269.0 \\
\hline Acid detergent fibre & 135.9 & 131.9 & 121.6 \\
\hline Indigestible neutral detergent fibre & 70.5 & 69.1 & 67.9 \\
\hline Total carbohydrates ${ }^{4}$ & 776.6 & 783.8 & 788.5 \\
\hline
\end{tabular}

Diets: SB - soybean meal; SBDY - soybean meal + dry yeast; DY - dry yeast

${ }^{1}$ Chemical composition (per kg of product) of commercial mixture ${ }^{\circledR}: \mathrm{Ca}-240.0 \mathrm{~g}$; P - 71.0 g; F - 710.0 mg (Max); Mg - 20.0 g; K - 28.2 g; S - 20.0 g; Fe - 2,500 mg; $\mathrm{Cu}$ - 400 mg; Mn - 1,350 mg; Zn - 1,700 mg; Co - 30 mg; I - 40 mg; Se - 15 mg; Cr - 10.00 mg; vitamin A - 135,000 IU; vitamin D3 - 68,000 IU; vitamin E - 450 IU.

${ }^{2}$ Estimated from rumen-degradable protein values of NRC (2007).

${ }^{3}$ Neutral detergent fibre assayed with a heat-stable amylase and expressed inclusive of residual ash.

${ }^{4}$ Estimated from Sniffen et al. (1992): TC $(\mathrm{g} / \mathrm{kg}$ of DM) $=1000-(\mathrm{CP}+\mathrm{EE}+\mathrm{ash})$. 
(TMR) and orts were collected for 6 consecutive days per period, during the days of faecal samples. Samples of feeds, orts, and faeces were collected for each period (postpartum, postpeak, and late lactation), frozen $\left(-20{ }^{\circ} \mathrm{C}\right)$, and a composite was formed on a period basis. Samples were oven-dried $\left(55^{\circ} \mathrm{C}\right.$ for $72 \mathrm{~h}$ ), then ground in a knife mill to pass through a $1 \mathrm{~mm}$ screen sieve.

The DM of diets, orts, and faeces was determined according to method no. 934.01 of the AOAC (1998). Ash was determined by combustion in a muffle furnace according to method no. 942.05 of the AOAC (1998). Total nitrogen (TN) was evaluated using a Tecnal TE-036/1 (Tecnal, Piracicaba, São Paulo, Brazil) following method no. 988.05 of the AOAC (1998) and CP was estimated as $\mathrm{TN} \times 6.25$. The ether extract content $(\mathrm{EE})$ in the diets was determined using a Tecnal TE-044/1 (Tecnal, Piracicaba, São Paulo, Brazil) according to method no. 920.39 of the AOAC (1998). Neutral detergent fibre (NDF) and acid detergent fibre (ADF) were measured according to the non-sequential procedures of Van Soest et al. (1991) using amylase but not sodium sulfite, and expressed inclusive of residual ash. Procedures for NDF determination were adapted for use in an Ankom 200 Fiber Analyzer (Ankom Technology Corp., Fairport, NY, USA).

Total carbohydrates (TC) and total digestible nutrients (TDN) were estimated according to equations described by Sniffen et al. (1992): TC $(\mathrm{g} / \mathrm{kg}$ of DM $)=1000-(\mathrm{CP}+\mathrm{EE}+$ ash $)$ and $\mathrm{TDN}=\mathrm{dCP}+(2.25 \times \mathrm{dEE})+\mathrm{dTC}$, in which $\mathrm{dCP}=$ digestible crude protein, $\mathrm{dEE}=$ digestible ether extract, and $\mathrm{dTC}=$ digestible total carbohydrates.

The dietary rumen-degradable protein (RDP) content was calculated according to the NRC (2007) model, bymultiplying the $\mathrm{CP}$ content by the concentration of RDP for each feed. The considered values were $725 \mathrm{~g} / \mathrm{kg}, 422 \mathrm{~g} / \mathrm{kg}$, and $644 \mathrm{~g} / \mathrm{kg}$ for corn silage, ground corn, and soybean meal, respectively. For inactive dry yeast, $0 \mathrm{~g} / \mathrm{kg}$ of RDP was adopted, since about $200 \mathrm{~g} / \mathrm{kg}$ of the nitrogen content is composed of nucleic acids (Amorim and Lopes, 2009).

Indigestible neutral detergent fibre (iNDF) was used as an internal marker to estimate faecal output and apparent nutrient digestibility. For iNDF analysis, $0.5 \mathrm{~g}(1 \mathrm{~mm})$ of period samples (faecal, orts, and feeds) were incubated in situ (144 h) in the goat rumen inside nylon bags (F57 Ankom), followed by neutral detergent analysis (Mertens, 2002) by an Ankon ${ }^{200}$ Fibre Analyzer (Ankom Technology Corp., Fairport, NY, USA).

Blood was collected from all goats 4 hours after the morning feeding to determine urea nitrogen (N-urea) concentration. Blood was withdrawn from the jugular vein into tubes, which were immediately centrifuged for $15 \mathrm{~min}$ at $3500 \mathrm{rpm}$. Serum was separated and frozen at $-20{ }^{\circ} \mathrm{C}$ for subsequent analysis. Serum samples were analysed using commercial kits (urea-PP kit category 427; Gold Analisa Diagnostica $^{\circledR}$ ) in a spectrophotometer (Shimadzu UV-1601 UV-Visable Spectrophotometer ${ }^{\circledR}$ ).

The economic evaluation was conducted using the concept of net profit of Cimmyt (1988), described by Borges et al. (2004). The net profit obtained is related to the revenue (value of milk production in treatment) minus the variable costs, which are costs that differ according to the treatment. The cost of food per kilogram of fresh matter (FM) quoted for the region of Maringá, in Brazilian Reais (R\$) values, was: ground corn, $0.43 \mathrm{R} \$ . \mathrm{kg}^{-1} \mathrm{FM}$; soybean meal, $0.98 \mathrm{R} \$ . \mathrm{kg}^{-1} \mathrm{FM}$; dry yeast, $0.75 \mathrm{R} \$ . \mathrm{kg}^{-1} \mathrm{FM}$; mineralvitamin supplement, $1.68 \mathrm{R} \$ . \mathrm{kg}^{-1} \mathrm{FM}$; and limestone, 0.48 $\mathrm{R} \$ . \mathrm{kg}^{-1} \mathrm{FM}$. For goat milk, the same value, $1.45 \mathrm{R} \$ . \mathrm{kg}^{-1}$, was used for all the treatments, and it is paid by the dairy company CAPRILAT ${ }^{\circledR}$.

The data obtained were analysed by analysis of variance $(\alpha=0.05)$ and means were compared by the Tukey test using the SAEG system (Sistema Para Análises Estatísticas e Genéticas, version 7.0), with the general model:

$$
Y_{i j k}=\mu+D_{i}+P_{j}+D P_{i j}+e_{i j k}
$$

in which $\mathrm{Y}_{\mathrm{ijk}}=$ the dependent variable; $\mu$ = general constant; $\mathrm{D}_{\mathrm{i}}=$ effect of diet $\mathrm{i}, \mathrm{i}=\mathrm{SB}$ (soybean meal), SBDY (soybean meal + dry yeast), and DY (dry yeast); $P_{j}=$ effect of the parity $j, j=1$ for primiparous and $j=2$ for multiparous; $\mathrm{DP}_{\mathrm{ij}}=$ interaction between diet $\mathrm{i}$ and parity $\mathrm{j}$; and $\mathrm{e}_{\mathrm{ijk}}=$ random error.

\section{Results}

The diets did not affect $(\mathrm{P}>0.05) \mathrm{DMI}$, organic matter intake (OMI), crude protein intake (CPI), neutral detergent fibre intake (NDFI), total carbohydrate intake (TCI), or intake of total digestible nutrients (TDNI) during the postpartum period for Saanen goats (Table 3).

Parity influenced $(\mathrm{P}<0.05)$ the DMI values and nutrients for Saanen goats in the postpartum period, with multiparous goats showing higher values than primiparous goats. Body weight (BW) and metabolic weight were not influenced $(\mathrm{P}>0.05)$ by diets. However, the BW of multiparous goats was $12.15 \mathrm{~kg}$ higher than that of primiparous goats.

There were no differences $(\mathrm{P}>0.05)$ in digestibility when goats were fed a diet with inactive dry yeast partially replacing soybean meal. However, when goats were fed inactive dry yeast as the only protein source, the EE digestibility was reduced $(\mathrm{P}<0.05)$.

Primiparous goats in the postpartum showed higher $(\mathrm{P}<0.05)$ digestibility of dry matter $(\mathrm{DDM})$, organic matter, 
$\mathrm{CP}, \mathrm{TC}$, and TDN than multiparous goats, resulting in greater TDN content.

Diets did not affect ( $\mathrm{P}>0.05)$ DMI ( $\mathrm{g} / \mathrm{kg}$ BW), TCI, or TDNI of Saanen goats postpeak fed diets with dry yeast (Table 4). However, EEI was greater $(\mathrm{P}<0.05)$ for goats fed $\mathrm{SB}$ than those fed dry yeast diets (SBDY or DY). The values of EEI, TCI, and TDNI $(\mathrm{P}<0.05)$ were influenced by parity postpeak. On the other hand, DMI expressed as a $\mathrm{g} / \mathrm{kg}$ of BW was not affected $(\mathrm{P}>0.05)$ by parity (Table 4$)$.

For DMI (kg/day and $\left.\mathrm{g} / \mathrm{kg}^{0.75}\right)$, OMI, CPI, and NDFI, there was a significant interaction between diets and parity. The primiparous goats fed the SBDY diet showed lower

Table 3 - Body weight, intake, digestibility and total digestible nutrients of primiparous and multiparous Saanen goats postpartum fed diets with dry yeast

\begin{tabular}{|c|c|c|c|c|c|c|c|c|c|}
\hline & \multicolumn{3}{|c|}{ Diets } & \multicolumn{2}{|c|}{ Parity } & \multirow{2}{*}{ SEM } & \multicolumn{3}{|c|}{ P-value } \\
\hline & $\mathrm{SB}$ & SBDY & DY & PRIM & MULT & & Diets & Parity & Interaction \\
\hline Body weight (kg) & 52.23 & 52.81 & 50.99 & 45.94 & 58.09 & 2.92 & 0.999 & 0.002 & 0.841 \\
\hline Metabolic body weight $\left(\mathrm{kg}^{0.75}\right)$ & 19.36 & 19.53 & 19.06 & 17.62 & 21.00 & 0.46 & 0.999 & 0.002 & 0.836 \\
\hline \multicolumn{10}{|l|}{ Intake (kg/day) } \\
\hline Dry matter & 1.76 & 1.63 & 1.66 & 1.31 & 2.06 & 0.07 & 0.909 & $<0.001$ & 1.000 \\
\hline Dry matter (g/kg BW) & 3.39 & 3.13 & 3.24 & 2.87 & 3.63 & 0.16 & 0.979 & 0.032 & 0.842 \\
\hline Dry matter $\left(\mathrm{g} / \mathrm{kg}^{0.75}\right)$ & 90.74 & 83.84 & 86.49 & 74.46 & 99.58 & 4.00 & 0.963 & 0.006 & 0.894 \\
\hline Organic matter & 1.69 & 1.56 & 1.60 & 1.25 & 1.98 & 0.06 & 0.931 & $<0.001$ & 1.000 \\
\hline Crude protein & 0.30 & 0.25 & 0.26 & 0.21 & 0.33 & 0.01 & 0.07 & $<0.001$ & 1.000 \\
\hline Ether extract & $0.06 \mathrm{a}$ & $0.04 \mathrm{~b}$ & $0.03 \mathrm{~b}$ & 0.03 & 0.05 & 0.002 & $<0.001$ & $<0.001$ & 0.991 \\
\hline Neutral detergent fibre & 0.47 & 0.41 & 0.39 & 0.31 & 0.54 & 0.03 & 0.664 & $<0.001$ & 1.000 \\
\hline Total carbohydrates & 1.33 & 1.28 & 1.31 & 1.01 & 1.60 & 0.05 & 1.000 & $<0.001$ & 0.999 \\
\hline Total digestible nutrients & 1.34 & 1.26 & 1.27 & 1.04 & 1.54 & 0.05 & 0.955 & $<0.001$ & 0.957 \\
\hline \multicolumn{10}{|l|}{ Digestibility (g/kg) } \\
\hline Dry matter & 750.7 & 773.7 & 759.3 & 783.9 & 738.5 & 4.4 & 0.13 & $<0.001$ & 0.10 \\
\hline Organic matter & 765.8 & 787.2 & 776.6 & 799.5 & 753.6 & 5.7 & 0.20 & $<0.001$ & 0.18 \\
\hline Crude protein & 739.1 & 742.7 & 736.9 & 755.9 & 723.8 & 4.8 & 0.997 & 0.003 & 0.10 \\
\hline Ether extract & $876.0 \mathrm{a}$ & $841.0 \mathrm{a}$ & $787.1 \mathrm{~b}$ & 844.4 & 825.0 & 7.6 & 0.002 & 0.22 & 0.907 \\
\hline Neutral detergent fibre & 453.0 & 497.5 & 437.4 & 476.4 & 44.8 .9 & 10.9 & 0.09 & 0.22 & 0.29 \\
\hline Total carbohydrates & 767.4 & 795.2 & 784.2 & 807.3 & 757.3 & 5.4 & 0.14 & $<0.001$ & 0.28 \\
\hline Total digestible nutrients & 767.5 & 782.5 & 770.7 & 797.7 & 749.4 & 4.7 & 0.643 & $<0.001$ & 0.15 \\
\hline
\end{tabular}

Means followed by different letters in the same row within diets differ $(\mathrm{P}<0.05)$.

Diets: SB - soybean meal; SBDY - soybean meal + dry yeast; DY - dry yeast.

Parity: PRIM - primiparous; MULT - multiparous.

Table 4 - Body weight, intake, digestibility and total digestible nutrients of primiparous and multiparous Saanen goats postpeak fed diets with dry yeast

\begin{tabular}{|c|c|c|c|c|c|c|c|c|c|}
\hline & \multicolumn{3}{|c|}{ Diets } & \multicolumn{2}{|c|}{ Parity } & \multirow{2}{*}{ SEM } & \multicolumn{3}{|c|}{ P-value } \\
\hline & SB & SBDY & DY & PRIM & MULT & & Diets & Parity & Interaction \\
\hline Body weight (kg) & 57.11 & 54.66 & 55.29 & 47.87 & 63.51 & 1.91 & 0.994 & $<0.001$ & 0.367 \\
\hline Metabolic body weight $\left(\mathrm{kg}^{0.75}\right)$ & 20.69 & 20.00 & 20.24 & 18.17 & 22.45 & 0.51 & 0.992 & $<0.001$ & 0.345 \\
\hline \multicolumn{10}{|l|}{ Intake (kg/day) } \\
\hline Dry matter & 2.18 & 1.80 & 1.92 & 1.61 & 2.33 & 0.07 & 0.135 & $<0.001$ & $0.028^{1}$ \\
\hline Dry matter (g/kg BW) & 3.92 & 3.33 & 3.54 & 3.44 & 3.75 & 0.14 & 0.225 & 0.258 & 0.068 \\
\hline Dry matter $\left(\mathrm{g} / \mathrm{kg}^{0.75}\right)$ & 106.66 & 90.43 & 96.29 & 90.27 & 105.31 & 3.37 & 0.166 & 0.039 & $0.042^{1}$ \\
\hline Organic matter & 2.09 & 1.79 & 1.89 & 1.59 & 2.26 & 0.07 & 0.225 & $<0.001$ & $0.040^{1}$ \\
\hline Crude protein & 0.36 & 0.32 & 0.32 & 0.28 & 0.40 & 0.01 & 0.239 & $<0.001$ & $0.040^{1}$ \\
\hline Ether extract & $0.09 \mathrm{a}$ & $0.06 \mathrm{~b}$ & $0.05 b$ & 0.06 & 0.08 & 0.002 & $<0.001$ & $<0.001$ & 0.141 \\
\hline Neutral detergent fibre & 0.64 & 0.50 & 0.50 & 0.45 & 0.64 & 0.03 & 0.077 & 0.003 & $0.043^{1}$ \\
\hline Total carbohydrates & 1.70 & 1.40 & 1.51 & 1.27 & 1.80 & 0.05 & 0.079 & $<0.001$ & 0.140 \\
\hline Total digestible nutrients & 1.70 & 1.38 & 1.48 & 1.25 & 1.79 & 0.05 & 0.060 & $<0.001$ & 0.123 \\
\hline \multicolumn{10}{|l|}{ Digestibility (g/kg) } \\
\hline Dry matter & 741.1 & 743.3 & 754.7 & 746.9 & 745.8 & 9.03 & 0.975 & 1.000 & $0.038^{1}$ \\
\hline Organic matter & 756.2 & 764.2 & 769.7 & 766.5 & 760.4 & 8.82 & 0.982 & 0.990 & $0.030^{1}$ \\
\hline Crude protein & 718.4 & 753.9 & 736.4 & 729.3 & 743.2 & 13.34 & 0.930 & 0.930 & 0.381 \\
\hline Ether extract & 885.8 & 825.2 & 803.0 & 833.5 & 842.4 & 5.73 & 0.785 & $<0.001$ & $0.003^{1}$ \\
\hline Neutral detergent fibre & $569.2 \mathrm{a}$ & $478.2 b$ & $466.8 b$ & 486.6 & 523.0 & 14.79 & 0.021 & 0.234 & 0.882 \\
\hline Total carbohydrates & 757.7 & 764.2 & 776.0 & 772.5 & 759.3 & 9.20 & 0.923 & 0.818 & $0.030^{1}$ \\
\hline Total digestible nutrients & 781.5 & 771.0 & 773.0 & 778.8 & 771.5 & 8.53 & 0.994 & 0.968 & $0.023^{1}$ \\
\hline
\end{tabular}

Means followed by different letters in the same row within diets differ $(\mathrm{P}<0.05)$

Diets: SB - soybean meal; SBDY - soybean meal + dry yeast; DY - dry yeast.

Parity: PRIM - primiparous; MULT - multiparous.

${ }^{1}$ The diet $\times$ parity interaction effects on these response parameters are shown in Table 5 . 
values for these intakes than those fed the SB and DY diets (Table 5).

The inclusion of dry yeast in the diet did not influence $(\mathrm{P}>0.05)$ the digestibility of crude protein $(\mathrm{dCP})$. However, the digestibility of neutral detergent fibre (dNDF) was reduced $(\mathrm{P}<0.05)$ by $9.67 \%$ when dry yeast was included in the diet. Parity had no effect ( $\mathrm{P}>0.05)$ on dCP or dNDF (Table 4).

For the digestibility of DM, OM, EE, TC, and TDN, there was an interaction $(\mathrm{P}<0.05)$ between diets and parity from Saanen goats postpeak. The lowest values for digestibility and TDN were observed for multiparous goats fed the SBDY diet (Table 5).
Diets did not alter $(\mathrm{P}>0.05)$ DMI, OMI, TCI, or TDNI of primiparous and multiparous Saanen goats in late lactation fed diets with dry yeast. However, differences $(\mathrm{P}<0.05)$ in CPI, EEI, and NDFI were found (Table 6).

Parity influenced $(\mathrm{P}<0.05) \mathrm{DM}$ and nutrient intake ( $\mathrm{kg} /$ day). On the other hand, it had no influence when DM and nutrient intake were calculated as a percentage of BW (Table 6).

Dry matter and nutrient digestibility were not influenced $(\mathrm{P}>0.05)$ by the diets. Ether extract digestibility was lower $(\mathrm{P}<0.05)$ in the animals fed the DY diet compared with those fed the other two diets. Parity had no effect

Table 5 - Interaction effect between the diets and the parity for intake, digestibility and total digestible nutrients of primiparous and multiparous Saanen goats postpeak fed diets with dry yeast ${ }^{1}$

\begin{tabular}{|c|c|c|c|c|c|c|}
\hline & \multicolumn{6}{|c|}{ Diets } \\
\hline & \multicolumn{2}{|c|}{ SB } & \multicolumn{2}{|c|}{ SBDY } & \multicolumn{2}{|c|}{ GY } \\
\hline & Primiparous & Multiparous & Primiparous & Multiparous & Primiparous & Multiparous \\
\hline \multicolumn{7}{|l|}{ Intake (kg/day) } \\
\hline Dry matter & 2.09 & 2.27 & 1.26 & 2.43 & 1.58 & 2.29 \\
\hline Dry matter $\left(\mathrm{g} / \mathrm{kg}^{0.75}\right)$ & 112.25 & 101.08 & 75.23 & 105.63 & 83.35 & 109.22 \\
\hline Organic matter & 2.01 & 2.19 & 1.22 & 2.35 & 1.53 & 2.26 \\
\hline Crude protein & 0.35 & 0.38 & 0.22 & 0.42 & 0.26 & 0.39 \\
\hline Neutral detergent fibre & 0.64 & 0.65 & 0.31 & 0.70 & 0.41 & 0.59 \\
\hline \multicolumn{7}{|l|}{ Digestibility (g/kg) } \\
\hline Dry matter & 718.8 & 763.7 & 779.2 & 707.3 & 742.6 & 766.7 \\
\hline Organic matter & 735.0 & 777.5 & 803.2 & 725.3 & 761.2 & 778.2 \\
\hline Ether extract & 872.6 & 898.9 & 852.8 & 797.6 & 775.1 & 828.9 \\
\hline Total carbohydrates & 737.9 & 777.6 & 808.6 & 720.2 & 771.8 & 780.2 \\
\hline Total digestible nutrients & 761.8 & 801.2 & 811.1 & 731.0 & 763.7 & 773.0 \\
\hline
\end{tabular}

Diets: SB - soybean meal; SBDY - soybean meal + dry yeast; DY - dry yeast.

${ }^{1}$ See Tables 4 for probability and SEM values.

Table 6 - Body weight, intake, digestibility and total digestible nutrients of primiparous and multiparous Saanen goats in late lactation fed diets with dry yeast

\begin{tabular}{|c|c|c|c|c|c|c|c|c|c|}
\hline & \multicolumn{3}{|c|}{ Diets } & \multicolumn{2}{|c|}{ Parity } & \multirow{2}{*}{ SEM } & \multicolumn{3}{|c|}{ P-value } \\
\hline & SB & SBDY & DY & PRIM & MULT & & Diets & Parity & Interaction \\
\hline Body weight (kg) & 61.34 & 62.23 & 58.47 & 53.72 & 67.64 & 2.14 & 0.950 & 0.004 & 0.996 \\
\hline Metabolic body weight $\left(\mathrm{kg}^{0.75}\right)$ & 21.82 & 22.09 & 21.11 & 19.82 & 23.54 & 0.57 & 0.956 & 0.004 & 0.997 \\
\hline \multicolumn{10}{|l|}{ Intake (kg/day) } \\
\hline Dry matter & 2.09 & 1.95 & 1.73 & 1.73 & 2.12 & 0.06 & 0.091 & 0.006 & 0.630 \\
\hline Dry matter (g/kg BW) & 3.53 & 3.18 & 2.95 & 3.23 & 3.21 & 0.14 & 0.248 & 1.000 & 0.351 \\
\hline Dry matter $\left(\mathrm{g} / \mathrm{kg}^{0.75}\right)$ & 97.52 & 88.83 & 81.52 & 87.21 & 91.37 & 3.38 & 0.182 & 0.878 & 0.318 \\
\hline Organic matter & 2.03 & 1.89 & 1.68 & 1.68 & 2.06 & 0.06 & 0.093 & 0.006 & 0.627 \\
\hline Crude protein & $0.35 \mathrm{a}$ & $0.33 \mathrm{ab}$ & $0.28 b$ & 0.29 & 0.35 & 0.01 & 0.035 & 0.004 & 0.376 \\
\hline Ether extract & $0.06 \mathrm{a}$ & $0.06 \mathrm{a}$ & $0.04 \mathrm{~b}$ & 0.05 & 0.06 & 0.002 & 0.001 & 0.008 & 0.729 \\
\hline Neutral detergent fibre & $0.49 \mathrm{a}$ & $0.40 \mathrm{ab}$ & $0.33 b$ & 0.36 & 0.45 & 0.02 & 0.025 & 0.047 & 0.775 \\
\hline Total carbohydrates & 1.59 & 1.51 & 1.34 & 1.34 & 1.63 & 0.05 & 0.161 & 0.006 & 0.625 \\
\hline Total digestible nutrients & 1.64 & 1.56 & 1.37 & 1.39 & 1.66 & 0.05 & 0.081 & 0.013 & 0.712 \\
\hline \multicolumn{10}{|l|}{ Digestibility (g/kg) } \\
\hline Dry matter & 772.2 & 777.4 & 778.0 & 789.7 & 762.0 & 9.38 & 1.000 & 0.087 & 0.673 \\
\hline Organic matter & 789.0 & 791.0 & 796.5 & 806.3 & 778.0 & 7.53 & 0.999 & 0.077 & 0.663 \\
\hline Crude protein & 758.6 & 757.1 & 738.1 & 751.2 & 751.3 & 7.88 & 0.734 & 1.000 & 1.000 \\
\hline Ether extract & $857.1 \mathrm{a}$ & $869.4 a$ & $798.3 b$ & 842.7 & 840.5 & 7.96 & 0.004 & 1.000 & 0.965 \\
\hline Neutral detergent fibre & 425.3 & 402.4 & 391.7 & 406.9 & 406.0 & 18.74 & 0.950 & 1.000 & 0.945 \\
\hline Total carbohydrates & 790.9 & 795.1 & 808.5 & 815.7 & 780.6 & 8.05 & 0.870 & 0.043 & 0.349 \\
\hline Total digestible nutrients & 787.7 & 800.6 & 797.8 & 809.1 & 781.6 & 7.44 & 0.953 & 0.081 & 0.674 \\
\hline
\end{tabular}

Means followed by different letters in the same row within diets differ $(\mathrm{P}<0.05)$.

Diets: SB - soybean meal; SBDY - soybean meal + dry yeast; DY - dry yeast.

Parity: PRIM - primiparous; MULT - multiparous. 
Table 7 - Serum urea nitrogen $(\mathrm{mg} / \mathrm{dL})$ of primiparous and multiparous Saanen goats in lactation fed diets with dry yeast

\begin{tabular}{|c|c|c|c|c|c|c|c|c|c|}
\hline \multirow{2}{*}{ Phase } & \multicolumn{3}{|c|}{ Diets } & \multicolumn{2}{|c|}{ Parity } & \multirow{2}{*}{ SEM } & \multicolumn{3}{|c|}{ P-value } \\
\hline & SB & SBDY & DY & PRIM & MULT & & Diets & Parity & Interaction \\
\hline Postpartum & $21.39 \mathrm{a}$ & $23.09 \mathrm{a}$ & $15.24 \mathrm{~b}$ & 21.20 & 18.61 & 0.89 & 0.005 & 0.162 & 0.955 \\
\hline Postpeak & 25.14 & 27.66 & 25.12 & 26.33 & 25.68 & 1.32 & 0.895 & 0.999 & 0.954 \\
\hline Late lactation & $32.66 \mathrm{a}$ & $31.50 \mathrm{a}$ & $21.94 \mathrm{~b}$ & 26.52 & 30.88 & 1.17 & 0.003 & 0.080 & 1.000 \\
\hline
\end{tabular}

Means followed by different letters in the same row within diets differ $(\mathrm{P}<0.05)$

Diets: SB - soybean meal; SBDY - soybean meal + dry yeast; DY - dry yeast.

Parity: PRIM - primiparous; MULT - multiparous.

Table 8 - Milk yield and net profit of milk (R\$) of primiparous and multiparous Saanen goats in lactation fed diets with dry yeast

\begin{tabular}{|c|c|c|c|c|c|c|c|c|c|}
\hline \multirow{2}{*}{ Phase } & \multicolumn{3}{|c|}{ Diets } & \multicolumn{2}{|c|}{ Parity } & \multirow{2}{*}{ SEM } & \multicolumn{3}{|c|}{ P-value } \\
\hline & SB & SBDY & DY & PRIM & MULT & & Diets & Parity & Interaction \\
\hline \multicolumn{10}{|c|}{ Milk yield (kg/day) } \\
\hline Postpeak & 3.49 & 3.18 & 3.34 & 2.71 & 3.71 & 0.23 & 0.651 & 0.002 & 0.012 \\
\hline Late lactation & 3.35 & 2.78 & 2.94 & 2.45 & 3.37 & 0.24 & 0.265 & 0.006 & 0.254 \\
\hline \multicolumn{10}{|c|}{ Net profit of milk (R\$) } \\
\hline Postpeak & 4,20 & 3.85 & 4.08 & 3.30 & 4.49 & 0.31 & 0.720 & 0.004 & 0.014 \\
\hline Late lactation & 4.03 & 3.27 & 3.59 & 2.90 & 4.07 & 0.32 & 0.274 & 0.007 & 0.246 \\
\hline
\end{tabular}

Means followed by different letters in the same row within diets differ $(\mathrm{P}<0.05)$

Diets: SB - soybean meal; SBDY - soybean meal + dry yeast; DY - dry yeast.

Parity: PRIM - primiparous; MULT - multiparous.

( $\mathrm{P}>0.05)$, except on TC; the highest value was obtained for primiparous goats in late lactation.

The total digestible nutrient values observed in late lactation period were higher than the estimated value (770 g/kg). The diets SB, SBDY, and DY showed TDN values that were $2.3,3.7$, and $3.61 \%$ higher than the estimated TDN, respectively.

The serum N-urea of lactating Saanen goats was influenced $(\mathrm{P}<0.05)$ by the diets. However, there was no difference $(\mathrm{P}>0.05)$ between the parities (Table 7).

The milk yield and the net profit of milk from primiparous and multiparous Saanen goats in lactation fed diets with dry yeast were not influenced $(\mathrm{P}<0.05)$ by the diets. However, there was a difference $(\mathrm{P}>0.05)$ between the parities (Table 8).

\section{Discussion}

Multiparous goats showed higher DMI, and therefore, higher nutrient intake than the primiparous goats for the three periods: postpartum (until the 60th lactation day), postpeak (61th to 130th day), and late lactation (131th to 200th day) (Table 3, 4, 5 and 6). The higher intake of the multiparous goats corresponds to their higher BW and greater gastrointestinal capacity, and the consequently higher nutrient requirement for maintenance.

The postpartum DMI $(\mathrm{kg} / \mathrm{day})$ of multiparous goats was $57.25 \%$ higher than that of primiparous goats.
However, this difference was reduced to $22.54 \%$ during late lactation. When compared with DMI as a percentage of BW, the difference between parities was reduced from early to late lactation. For multiparous goats, during postpartum and postpeak, this difference was $26.48 \%$ and $9.01 \%$, respectively, and during late lactation, there was no difference between the parities $(0.62 \%)$. Thus, the values showed in this study ranging from $2.87 \mathrm{~g} / \mathrm{kg}$ to $3.92 \mathrm{~g} / \mathrm{kg}$ were similar to recent studies on lactating goats that showed DMI (g/kg BW) ranging from $2.93 \mathrm{~g} / \mathrm{kg}$ to $4.50 \mathrm{~g} / \mathrm{kg}$ (Fonseca et al., 2008; Serment et al., 2011)

According to the NRC (2007), the intake of animals is based on a combination of factors, such as its energy requirement, characteristics of the feed, $\mathrm{BW}$, and $\mathrm{BW}$ at maturity. Lima et al. (2012) reported higher DMI for 2-yearold goats compared with 1-year-old goats. This difference was attributed to the different BW $(10.69 \mathrm{~kg})$ between the ages at the first kidding.

The goats have the ability to select foods according to palatability and may reject some foods partially or fully concentrated. Because dry yeast has specific flavor, which is dependent on the substrate on which it was grown (Amorim and Lopes, 2009), in this case the sugarcane, this factor may have contributed to the decrease in the intake of primiparous goats that received rations where the soybean meal was totally or partially replaced by dry yeast.

According to Van Soest (1982), high NDF values can interfere with DM intake; values above $480-500 \mathrm{~g} / \mathrm{kg}$ of 
NDF reduce the silage quality and consequently decrease consumption rates. In this study, the DM intake was slightly lower than expected, as the estimated DM intake for goats is approximately $3 \mathrm{~kg}$ /day (NRC, 2007). So, one possible explanation for this observation is the silage used was of low quality and had a fibre content of $569 \mathrm{~g} / \mathrm{kg}$ of DM.

Goats fed diets without dry yeast (SB) showed higher EEI and NDFI than those fed dry diets (SBDY and DY). This may be explained by the higher EE and NDF content in soybean meal $(29 \mathrm{~g} / \mathrm{kg})$ compared with dry yeast $(1.8 \mathrm{~g} / \mathrm{kg})$ (Table 1).

When goats were fed inactive dry yeast as the only protein source, the EE digestibility was reduced during the postpartum and the late lactation periods. This can be explained by the lower EE intake observed in this $\operatorname{diet}$ (DY). The reduction in EE digestibility was due to the lower EEI observed with the DY diet. This is in agreement with the results reported by Rufino et al. (2013), which showed an effect on EE digestibility when lambs were fed dry yeast as a soybean meal substitute.

The TDN value observed for primiparous goats was higher than the previous estimate $(770 \mathrm{~g} / \mathrm{kg})$, so primiparous goats were more efficient in the use of the nutrients in this phase. The TDN values observed among goats fed the $\mathrm{SB}, \mathrm{SBDY}$, and DY diets corresponded to the previously estimated TDN value of $770 \mathrm{~g} / \mathrm{kg}$. It indicates that iNDF is a good internal marker for digestibility trials.

During the postpartum and late lactation phases, in goats fed the DY diet, the N-urea concentration was reduced compared with goats fed the other two diets. This corresponds to the better synchrony between the degradation rates, and protein and energy utilisation of the DY diet, and the higher RDP. The lowest $\mathrm{N}$-urea values were found during the postpartum phase, which may be due to greater nitrogen utilisation efficiency in this period.

The mixture of ingredients in the diets resulted in different concentrations of N-urea: from 15.24 to 32.66 $\mathrm{mg} / \mathrm{dL}$. Brun-Bellut et al. (1991) observed in lactating Saanen goats fed $133 \mathrm{~g} / \mathrm{kg} \mathrm{CP}$ an N-urea concentration of $21.9 \mathrm{mg} / \mathrm{dL}$. Fonseca et al. (2008) observed a mean value of $25.73 \mathrm{mg} / \mathrm{dL}$ for Alpine goats fed diets containing different protein levels (115 g/kg to $175 \mathrm{~g} / \mathrm{kg}$ ). Mendes et al. (2010) evaluated the replacement of soybean meal by urea or starch-urea in the diets for Saanen-Alpine goats and observed $\mathrm{N}$-urea values ranging from 24.42 to $34.92 \mathrm{mg} / \mathrm{dL}$.

The net profit of milk correlates with milk yield, so the higher yield of multiparous goats results in greater net profit of milk compared with primiparous goats. According to Sauvant et al. (2012), the average daily production of goats depends on parity; and multiparous goats tend to produce more than primiparous goats. Also, the fact that the diets did not change the net profit of milk shows that dry yeast is an alternative to soybean meal in diets for goats. However, for the utilisation of dry yeast instead of soybean meal, a sensitivity analysis should be performed first, because the cost of feeds changes constantly; the cost of $\mathrm{CP}$ per kilogram is higher for dry yeast compared with soybean meal: for dry yeast it is $1.86 \mathrm{R} \$ . \mathrm{kg}^{-1}$ and for soybean meal it is $1.82 \mathrm{R} \$ . \mathrm{kg}^{-1}$.

\section{Conclusions}

Inactive dry yeast is a good alternative protein source to soybean meal in diets for primiparous and multiparous lactating Saanen goats, because it does not affect the DM and nutrient intake and digestibility, or the nutritive value of diets.

\section{References}

Amorim, H. V. and Lopes, M. L. 2009. Tecnologia sobre processamento de leveduras vivas, inativas e seus derivados: conceitos básicos. p.5-19. In: Anais do 1o Congresso sobre Uso de Levedura na Alimentação Animal. Colégio Brasileiro de Nutrição Animal, Campinas.

Araújo, F. F. and Silva, C. C. 2009. Leveduras hidrolisadas e inativas. p.37-44. In: Anais do 1ำ Congresso Internacional sobre o Uso de Levedura na Alimentação Animal. Colégio Brasileiro de Nutrição Animal, Campinas.

AOAC - Association of Official Agricultural Chemists. 1998. Official methods of analysis. 16th ed. Association of Official Analytical Chemists, Gaithersburg.

Borges, P. H. R.; Azevedo, A. R.; Sales, R. O.; Arruda, F. A. V. and Alves, A. A. 2004. Desempenho de ovinos alimentados com diferentes níveis de pseudofruto seco do cajueiro. Revista Científica de Produção Animal 3:24-34.

Brun-Bellut, J.; Kelly, J. M.; Mathison, G. W. and Chrisropherson, R. J. 1991. Effect of rumen degradable protein and lactation on nitrogen metabolism in dairy goats. Canadian Journal of Animal Science 71:1111-1124.

EURASYP - European Association for Specially Yeast Products. 2006. Yeast products: Yeast cell wall. Available at: $<$ http://www.eurasyp. org/public.levure.aliment.screen> Accessed on: Jan. 2, 2011.

Fonseca, C. E. M.; Valadares, R. F. D.; Valadares Filho, S. C.; Leão, M. I. and Marcondes, M. I. 2008. Digestão dos nutrientes e balanço de compostos nitrogenados em cabras alimentadas com quatro níveis de proteína. Arquivo Brasileiro de Medicina Veterinária e Zootecnia 60:192-200.

Lima, L. S.; Alcalde, C. R.; Freitas, H. S.; Molina, B. S. L.; Macedo, F. A. F. and Horst, J. A. 2012. Performance of dairy goats fed diets with dry yeast from sugar cane as protein source. Revista Brasileira de Zootecnia 41:232-236.

Mendes, C. Q.; Fernandes, R. H. R.; Susin, I.; Pires, A. V. and Gentil, R. S. 2010. Substituição parcial do farelo de soja por ureia ou amireia na alimentação de cabras em lactação. Revista Brasileira de Zootecnia 39:1818-1824.

Mertens, D. R. 2002. Gravimetric determination of amylase-treated neutral detergent fiber in feeds with refluxing in beaker or crucibles: collaborative study. Journal of AOAC International 85:1217-1240.

NRC - National Research Council. 2007. Nutrient requirements of small ruminants. National Academy Press, Washington, D.C. 
Peixoto, L. A. O. and Osório, M. T. M. 2007. Perfil metabólico protéico e energético na avaliação do desempenho reprodutivo em ruminantes. Revista Brasileira Agrociência 13:299-304.

Pina, D. S.; Valadares Filho, S. C.; Valadares, R. F. D.; Campos, J. M. S; Detmann, E.; Marcondes, M. I.; Oliveira, A. S. and Teixeira, R. M. A. 2006. Consumo e digestibilidade aparente total dos nutrientes, produção e composição do leite de vacas alimentadas com dietas contendo diferentes fontes de proteína. Revista Brasileira de Zootecnia 35:1543-1551.

Rodrigues, C. A. F.; Rodrigues, M. T.; Branco, R. H.; Silva, M. M. C.; Torres Filho, R. A. and Queiroz, A. C. 2007. Consumo, digestibilidade e produção de leite de cabras leiteiras alimentadas com dietas contendo diferentes níveis de proteína bruta e energia líquida. Revista Brasileira de Zootecnia 36:1658-1665.

Rufino, L. D. A; Pereira, O. G.; Ribeiro, K. G.; Valadares Filho, S. C.; Cavali, J. and Paulino, P. V. R. 2013. Effect of substitution of soybean meal for inactive dry yeast on diet digestibility, lamb's growth and meat quality. Small Ruminant Research 111:56-62.
Sauvant, D.; Giger-Reverdi, S.; Meschy, F.; Puillet, L. and Schmidely, P. 2012. Updating nutritional recommendations for dairy goats. INRA Productions Animales 25:259-275.

Serment, A.; Schmidely, P.; Giger-Reverdin, S.; Chapoutot, P. and Sauvant, D. 2011. Effects of the percentage of concentrate on rumen fermentation, nutrient digestibility, plasma metabolites, and milk composition in mid-lactation goats. Journal of Dairy Science 94:3960-3972.

Sniffen, C. J.; O’Connor, J. D.; Van Soest, P. J.; Fox, D. G. and Russel, J. B. 1992. A net carbohydrate and protein system for evaluating cattle diets: II. Carbohydrate and protein availability. Journal of Animal Science 70:3562-3577.

Van Soest, P. J.; Robertson, J. B. and Lewis, B. A. 1991. Methods for dietary fiber, neutral detergent fiber, and nonstarch polysaccharides in relation to nutrition. In: Symposium Carbohydrate Methodology, Metabolism, and Nutritional Implications in Dairy Cattle. Journal of Dairy Science 74:3583-3597.

Van Soest, P.J. 1982. Nutritional ecology of the ruminant. Cornell University Press, Ithaca. 